\title{
The Ongoing Shift of Mediterranean \\ Coastal Fish Assemblages and the Spread of Non-Indigenous Species
}

\author{
Stefanos Kalogirou, Ernesto Azzurro and Michel Bariche \\ Additional information is available at the end of the chapter
}

http://dx.doi.org/10.5772/50845

\section{Introduction}

Geological history of life on earth tells that continents have been isolated for long periods. It also reveals that collisions of land masses as well as lower sea levels allowed the spread of fauna and flora (Stachowicz and Tilman, 2005). In today's seas, marine communities are being altered and remodelled at an unprecedented rate, when compared to natural changes which occured over geological times. While many marine species populations are dwindling due to overfishing and habitat destruction (Jackson et al., 2001), other species are invading new areas through anthropogenic vectors (Carlton 1985, Galil 2006, Galil et al. 2007). During the last centuries, human transport has increased the number of non-indigenous species (NIS) introductions. For example, half of the plant species of Hawaii are exotics (Sax et al., 2002) as are about $20 \%$ of plants in California bay (Sax, 2002) and about $18 \%$ of fish species in the eastern Mediterranean Sea (Golani et al. 2002, Golani et al. 2006, EastMed 2010, Golani 2010).

Understanding invasion ecology requires a good knowledge of ecological processes in the systems under study, prior to invasion. Diversity, structure, and function of natural communities would give insights into fundamental ecological processes which could in turn give a better understanding of potential effects following the introduction of NIS.

From a societal perspective, species invasions might pose serious threats to human economic interests and health (Yang et al., 1996; Sabrah et al., 2006; Katikou et al., 2009). Species invasions have also been considered to have negative impacts on native biodiversity (Reise et al., 2006; Streftaris and Zenetos, 2006; Galil, 2007; Lasram and Mouillot, 2008; Zenetos et al., 2009). Furthermore, invasions interacts with other disturbing factors to the marine ecosystem functioning such as habitat destruction, pollution and climate change 
(Rilov and Crooks, 2009). Disturbance caused by habitat destruction may open up space for invaders but space can also be released by the invaders themselves. Consider the example given by Rilov and Galil (2009) where two non-indigenous siganids might have modified the competition between algae and mussels through intensive grazing, thus providing space for the non-indigenous mussel Brachiodontes pharaonis. Pollution can make environmental conditions less tolerable for native species, and perhaps provide opportunities for opportunists, among which non-indigenous species could be found (Occhipinti-Ambrogi and Savini, 2003; Wallentinus and Nyberg, 2007). Global warming is causing the shifts and poleward migrations of many taxa that are now extending their biogeographical range (Parmesan and Yohe, 2003; Perry et al., 2005). This tendency is also observed in the Mediterranean Sea (Bianchi, 2007; Raitsos et al., 2010). Some species, typically confined to the warmer parts of the Mediterranean, are currently colonizing the northern sectors. This phenomenon has been termed "meridionalization" (Azzurro, 2008).

The increase of water temperature is also allowing the success of tropical exotic species in the Mediterranean Sea, a phenomenon that has been called 'tropicalization' (Bianchi and Morri, 2003). Conditions facilitating invasions are usually related to the physical and biological attributes of the new colonized habitats. Biological impact studies include mostly those species of economic interests (e.g. fisheries) (Streftaris and Zenetos, 2006), human health (e.g. toxic species) (Yang et al., 1996; Bentur et al., 2008; Katikou et al., 2009) and biodiversity (e.g. competition with indigenous species or habitat modifiers) (Golani, 1993a; Golani, 1994; Bariche et al., 2004; Azzurro et al., 2007a; Kalogirou et al., 2007; Wallentinus and Nyberg, 2007; Bariche et al., 2009). A lot of research has also focused on the factors controlling success or failure of invasive species by considering mechanisms of interactions between indigenous and NIS. There is no universal model explaining the mechanisms controlling the success or failure of an invading species (Stachowicz and Tilman, 2005). As far as the Mediterranean Sea is concerned, important mechanisms include competition for resources or space (Bariche et al., 2004; Kalogirou et al., 2007), top-down forces (Goldschimdt et al., 1993), herbivory (Lundberg and Golani, 1995; Galil, 2007), and parasites (Diamant, 2010).

A widely cited theory in invasion ecology is about the relationship between diversity and invasibility of an ecosystem (i.e. more diverse communities should be more resistant to invasion) (Leppäkoski and Olenin, 2000). The mechanism suggests that as species richness increases the competition intensifies and less food resources remain available for new colonizers (MacArthur, 1955; Levine and D' Antonio, 1999). Less diverse ecosystems possessing fewer species and simpler food-web interactions would therefore provide available niches for the establishment of NIS. This hypothesis is known as the "biotic resistance hypothesis" (Levine and Adler, 2004). As an aid to understand this mechanism, both observational and experimental approaches have been applied with conflicting results (Levine and D' Antonio, 1999). Studies that employ both observational and experimental approaches show that high diverse systems does reduce invasion success (Stachowicz and Tilman, 2005). There is a long history of theoretical discussions about the relationship between species richness and productivity or stability of a system. Threats to global species 
diversity caused by human activities have raised concern on the consequences of species losses to the functioning of ecosystems. In ecology, this concern has received a lot of attention. During the last 20 years, experimental tests of the relationship between species richness and ecosystem processes such as productivity, stability and invasibility have increased rapidly (Stachowicz and Whitlatch, 1999).

Other theories go back to the work of Darwin. Darwin's "naturalization hypothesis" predicts that NIS are less prone to invade areas where closely related species are present. Those species would compete with their relatives and would encounter predators and pathogens. An opposing view is the "pre-adaptation" hypothesis predicting that NIS should succeed in areas where indigenous closely related species are present because they are more likely to share traits that pre-adapt them to their own environment. So far, these theories have been seldom tested on fish species and no clear pattern has emerged so far for these taxa (Ricciardi and Mottiar (2006). Ricciardi and Mottiar (2006) agreed with Moyle and Light (1996) that success is primarily determined by competitive interactions (e.g. "biotic resistance" hypothesis), propagulae pressure and environmental abiotic factors (i.e. the degree to which NIS physiological tolerances are compatible to local physical conditions). Rapid changes in environmental conditions, caused by human activities, have also been mentioned as to increase invasiveness (Occhipinti-Ambrogi and Savini, 2003). Habitats that lack predators are also suggested to be more prone to introductions of NIS (Moyle and Light, 1996). There is also a higher risk of further establishment of species in habitats that have already been invaded, referred as the "invasional meltdown" (Simberloff and Von Holle, 1999; Ricciardi, 2001). In a study from Great Lakes, Ricciardi (2001) found support for the "invasional meltdown" hypothesis by showing that positive interactions (mutualistic) among NIS are more common than negative (competitive). In further support of the "invasional meltdown" hypothesis, Ricciardi (2001) showed that exploitative interactions (e.g. predator-prey) among NIS are strongly asymmetrical to the benefit of one invading species at a negligible cost to another.

\section{Current patterns of change of the Mediterranean biota}

In the last century the Mediterranean Sea has been a receptacle of NIS, most of them arrived by mean of direct or indirect mediation of humans. Today, the Mediterranean Sea can be considered as one of the main hotspots of marine bio-invasions on earth (Quignard and Tomasini, 2000), and is by far the major recipient of NIS among European seas including macrophytes, invertebrates and fishes (Streftaris et al., 2005; Zenetos et al., 2010). The Mediterranean is unique because of its connection to the Indo-West Pacific realm via the Suez Canal (Fig. 1), allowing the so called Lessepsian migration (Por, 1978). The rate of this immigration has increased in recent decades and has ecological, social and economic impacts (Zenetos et al., 2008; Bilecenoglu, 2010; Zenetos et al., 2010). The Eastern Mediterranean basin is potentially more prone to introductions of subtropical and tropical NIS than the western basin. This has been mainly attributed to different physical and biological conditions between the two basins. It is to mention that the construction of the 
Aswan Dam on the Nile River in 1966 reduced significantly the freshwater flood into the Mediterranean Sea. This led to an increased salinity of 2-3\% along the Mediterranean coast of Egypt and to a reduction of the most important sources of nutrients in the eastern Mediterranean Sea (Galil, 2006). The damming of the Nile might have positively favoured the westward dispersion of Lessepsian NIS along the Northern African shores (Ben-Tuvia, 1973).

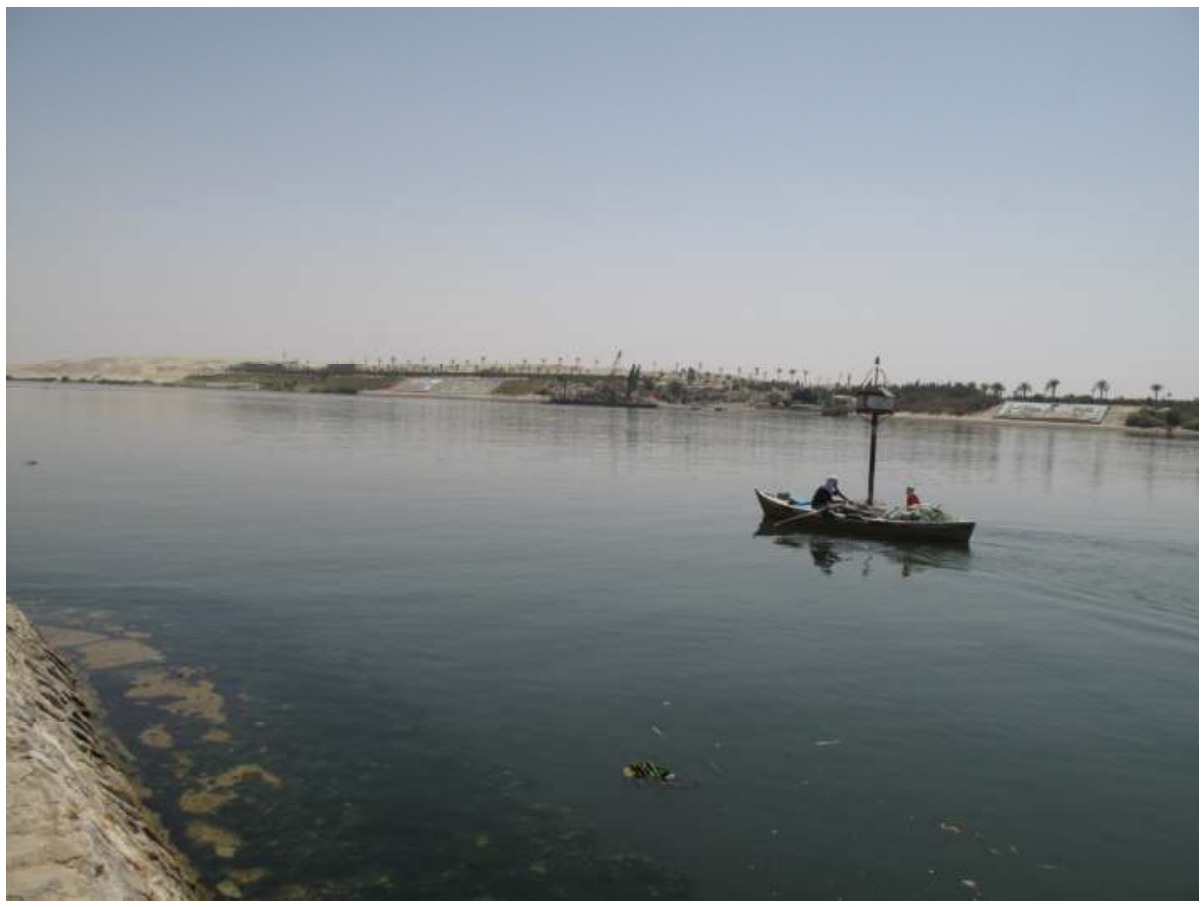

Figure 1. The Suez Canal

New terms have been recently created to describe current changes of the Mediterranean biodiversity. Due to the tropical nature of most of the exotic species that enter the Mediterranean, various authors have defined the process of entrance and spread of these organisms as 'tropicalization' (Bianchi and Morri, 2004; Bianchi, 2007). Another definition that has been used is "demediterranization"(Quignard and Tomasini, 2000) that put the emphasis on the process of biotic homogenization of the Mediterranean Sea. Instead Massuti et al. (2010) used the term 'meridianization' to indicate the increasing divergence (in terms of composition of the biological communities) between the Eastern and Western sectors of the Mediterranean, due to the continuous influx of Lessepsian and Atlantic biota. This latter term, 'meridianization' should not be confused with 'meridionalization', which instead would indicate the northward expansion of southern ('meridional') species towards the northern sectors of the basin (Azzurro, 2008). Several indigenous species such as Sparisoma cretense and Thalassoma pavo have been regarded as "meridional" (CIESM, 2008) since they 
have been recently found to reproduce and have established populations in the coldest part of the Mediterranean Sea (Ligurian Sea) (Guidetti et al., 2002). Additionally, a reduction of temperate species followed the increase of tropical species in the Ligurian Sea (Bianchi and Morri, 2003). These trends of change in the biological diversity of the Mediterranean Sea are part of a general reshuffling of species, that is happening at the global level (Vitousek et al., 1997), and climate warming would contribute to promote the shifts of species distribution, an evidence that is particularly clear among marine fishes (Perry et al., 2005). As fish are particularly sensitive to changes in water temperatures, physiological processes directly alters behaviour, generating active movement and migratory patterns of these organisms (Roessig et al., 2004). Other indirect effects of climate change, such as those related to the change of currents, could affect larval dispersal, retention and recruitment of marine organisms (Bianchi and Morri, 2004).

More than 700 fish species inhabit the Mediterranean Sea with a general decrease in number moving eastwards (Quignard and Tomasini, 2000; Lasram et al., 2009) . Among these, at least 80 are non-indigenous of Indo-West Pacific and Red Sea origin (Cicek and Bilecenoglu, 2009; Bariche, 2010b; EastMed, 2010; Golani, 2010; Bariche, 2011b; Sakinan and Örek, 2011; Salameh, 2011; Bariche and Heemstra, 2012). The abundance of these nonindigenous species is not well documented. The list of non-indigenous fish species with quantitative information from the Mediterranean Sea can be found in Table 1.

\begin{tabular}{|c|c|c|}
\hline Family & Species & Reference \\
\hline Atherinidae & Atherinomorus forskalii & $\begin{array}{l}\text { (Bariche et al., 2007; Shakman and } \\
\text { Kinzelbach, 2007) }\end{array}$ \\
\hline Callionymidae & Callionymus filamentosus & (Gucu and Bingel, 1994; Kalogirou et al., 2010) \\
\hline Carangidae & Alepes djedaba & (Shakman and Kinzelbach, 2007) \\
\hline Clupeidae & Etrumeus teres & $\begin{array}{l}\text { (Bariche et al., 2006; Bariche et al., 2007; } \\
\text { Carpentieri et al., 2009) }\end{array}$ \\
\hline Clupeidae & Herklotsichthys punctatus & $\begin{array}{l}\text { (Bariche } \text { et al., 2006; Bariche et al., 2007; } \\
\text { Carpentieri et al., 2009) }\end{array}$ \\
\hline Dussumieriidae & Dussumieria elopsoides & (Goren and Galil, 2005; Bariche et al., 2007) \\
\hline Fistulariidae & Fistularia commersonii & $\begin{array}{l}\text { (Shakman and Kinzelbach, 2007; Carpentieri } \\
\text { et al., 2009; Kalogirou et al., 2010; Kalogirou } \\
\text { et al., 2012b) }\end{array}$ \\
\hline Hemiramphidae & Hemiramphus far & $\begin{array}{l}\text { (Shakman and Kinzelbach, 2007; Carpentieri } \\
\text { et al., 2009) }\end{array}$ \\
\hline Holocentridae & Sargocentron rubrum & (Carpentieri et al., 2009) \\
\hline Labridae & Pteragogus pelycus & (Kalogirou et al., 2010) \\
\hline Leiognathidae & Leiognathus klunzingeri & (Gucu and Bingel, 1994) \\
\hline Monacanthidae & Stephanolepis diaspros & $\begin{array}{l}\text { (Gucu and Bingel, 1994; Harmelin-Vivien et } \\
\text { al., 2005; Shakman and Kinzelbach, 2007; } \\
\text { Carpentieri et al., 2009; Kalogirou et al., 2010; } \\
\text { Kalogirou et al., 2012b) }\end{array}$ \\
\hline
\end{tabular}


Mullidae Upeneus moluccensis

Mullidae

Upeneus pori

Nemipteridae
Pempheridae
Scaridae

Nemipterus randalli

Pempheris vanicolensis

Scarus ghobban

Scombridae

Siganidae

Siganidae

Sphyraenidae

Sphyraenidae Synodontidae

Pempheridae

Pomacentridae

Tetraodontidae

Tetraodontidae

Tetraodontidae
Sphyraena flavicauda Saurida undosquamis

Pempheris vanicolensis

Sarogentrum rubrum

Lagocephalus sceleratus

Lagocephalus spadiceus

Scomberomorus

commerson

Siganus luridus

Siganus rivulatus

Sphyraena chrysotaenia

Lagocephalus suezensis
(Gottlieb, 1960; Oren et al., 1971; Gucu and Bingel, 1994; Golani and Ben-Tuvia, 1995;

Sonin et al., 1996; Goren and Galil, 2005;

Harmelin-Vivien et al., 2005; Carpentieri et al., 2009; Kalogirou et al., 2010)

(Gucu and Bingel, 1994; Golani and BenTuvia, 1995; Goren and Galil, 2005; Shakman and Kinzelbach, 2007; Carpentieri et al., 2009; Kalogirou et al., 2010; Kalogirou et al., 2012b)

(Carpentieri et al., 2009)

(Carpentieri et al., 2009)

(Bariche and Saad, 2008; Carpentieri et al., 2009)

(Shakman and Kinzelbach, 2007; Carpentieri et al., 2009)

(Gucu and Bingel, 1994; Bariche et al., 2004; Harmelin-Vivien et al., 2005; Shakman and Kinzelbach, 2007; Carpentieri et al., 2009; Kalogirou et al., 2010; Kalogirou et al., 2012b) (George and Athanassiou, 1967; Bariche et al., 2004; Bariche, 2005; Harmelin-Vivien et al., 2005; Shakman and Kinzelbach, 2007; Carpentieri et al., 2009; Kalogirou et al., 2010; Kalogirou et al., 2012b)

(Golani and Ben-Tuvia, 1995; Carpentieri et al., 2009; Kalogirou et al., 2010; Kalogirou et al., 2012a)

(Kalogirou et al., 2012b)

(Oren et al., 1971; Ben-Yami and Glaser, 1974; Gucu and Bingel, 1994; Golani and Ben-Tuvia, 1995; Galil and Zenetos, 2002; Goren and Galil, 2005; Harmelin-Vivien et al., 2005; Shakman and Kinzelbach, 2007; Carpentieri et al., 2009) (Harmelin-Vivien et al., 2005) (Harmelin-Vivien et al., 2005) (Carpentieri et al., 2009; Kalogirou et al., 2010; Aydin, 2011; Kalogirou et al., 2012b)

(Carpentieri et al., 2009)

(Carpentieri et al., 2009; Kalogirou et al., 2010)

Table 1. List of the non-indigenous fish species of Indo-Pacific and Red Sea origin with references on quantitative information in abundance in the Mediterranean Sea 
The arrival of these invaders raises plain concern on the ecological and economic impact that such migrants have but the available information is still scarce (Rilov and Galil, 2009) and there is an obvious lack of knowledge. It is at the same time obvious that the ecological effect of some species is significant (Kalogirou et al., 2007; Bariche et al., 2009). Competitive exclusion and displacement of native species are often potential expectations in ecological studies (Bariche et al., 2004; Galil, 2007). A noteworthy example is the presence of the two Lessepsian herbivorous Siganus rivulatus and S. luridus. The impact of the two species on indigenous species has received some scientific attention and comments (Bariche et al., 2004; Azzurro et al., 2007b; Galil, 2007; Golani, 2010). Since their first record in the Mediterranean Sea, respectively 1924 and 1955, the two species have established significant populations in the eastern basin and have spread westwards as far as Sicily and Tunisia (Rilov and Galil, 2009). They constituted one third of the fish biomass over hard bottoms and their contribution to the guild of herbivorous fish species in shallow coastal areas reached $80 \%$ along the Levantine coast (Goren and Galil, 2001; Bariche et al., 2004). The two siganids are commercially important in the eastern Mediterranean Sea. The native herbivorous Sarpa salpa (Sparidae) was relatively an abundant species and a possible competition with $S$. rivulatus was already highlighted along the coast of Lebanon (Gruvel, 1931; George and Athanassiou, 1967). Nowadays, records of S. salpa from Lebanon are very scarce and it has been suggested that the native species has been outcompeted by the Lessepsian invaders (Bariche et al., 2004; Galil, 2007). In contradiction, Golani (2010) rejected this hypothesis and considered that Gruvel was unable to recognize S. salpa from another common sparid Boops boops. We consider that this assumption is not accurate as Gruvel described separately B. boops (as Box vulgaris C.V. = Box boops L.) and S. salpa (Box salpa Cuv.) and made clear reference to their local abundance and flesh palatability, showing that he knew well how to identify them (Gruvel, 1931). The author was assessing the fishery resources of the Levantine coast by mean of experimental trawling. The clear competitive superiority of siganids may be due to a greater adaptability to fluctuating environmental conditions and other biological advantages (Bariche et al., 2004). Moreover, macrophytes are considered to be abundant along the eastern Mediterranean coast (Lipkin and Safriel, 1971; Lundberg and Golani, 1995). Lundberg \& Golani (1995) compared the stomach contents of the siganids in relation to food availability in the source (Red Sea) and invaded (Mediterranean Sea) areas. They found a scarcity of food species underwater and abundance on vermetid reefs and beach rocks, which are situated at sea level and are thus rather inaccessible (Lundberg and Golani, 1995; Lundberg et al., 2004). Siganus rivulatus and S. luridus were shown to be selective in the eastern Mediterranean, when macrophytes are diverse and abundant and will eat what is available when food is scarce (Bariche, 2006). Selectivity being more important in the Mediterranean Sea is probably due to a larger choice in food species (Golani, 1993b; Lundberg et al., 2004). Nevertheless, the success of siganids also shows a larger trophic or eco-physiological flexibility in the Mediterranean Sea (Hassan et al., 2003; Bariche, 2006). This also reveals the lack of available data regarding herbivorous Lessepsian siganids being better competitors than indigenous ones for food until it is proven that trophic resources constitute the most important limiting factor (Golani, 2010). Finally, 
negative consequences of fish invasions are not only restricted to native fish communities. The intensive grazing of macrophytes by the same siganids might have reduced the competition between algae and mussels, and thus released space for the establishment of a non-indigenous mussel, Brachiodontes pharaonis, on rocky shores along the coasts of the Levant (Rilov and Galil, 2009).

\section{The case of the invasive pufferfish Lagocephalus sceleratus: Ecological consequences, economic impacts and risks for human health}

Pufferfishes are marine fish species that are distributed in tropical and subtropical areas of the Atlantic, Indian and Pacific Ocean. Puffers include 121 species within the Tetraodontidae family among which nine (T. flavimaculosus, L. sceleratus, L. spadiceus, L. suezensis, S. pachygaster, S. spengleri, T. spinosissimus, S. marmoratus, L. lagocephalus) are found in the Mediterranean Sea. Some puffers contain the strongest paralytic toxin known to date, tetrodotoxin (Sabrah et al., 2006). European legislation (854/2004/EC) states that toxic fish of the Tetraodontidae family should not enter the European markets. In a global perspective, occasional accidental poisonings have lead to numerous human deaths, the majority of which have been documented in southeastern Asia, including Malaysia, Taiwan, Hong Kong, and Korea (Kan et al., 1987; Yang et al., 1996).

Lagocephalus sceleratus received considerable public attention shortly after its first record in 2003 from the Gökova bay in the south-eastern coasts of the Aegean Sea due to the presence of significant amounts of tetrodotoxin (Akyol et al., 2005). The distribution of L. sceleratus is currently limited to the eastern Mediterranean Sea but the species is showing a rapid spread westward.

Few dozens of tetrodotoxin poisoning cases occurred along the Levantine coast and in Cyprus (Bentur et al., 2008). Lagocephalus spadiceus, which has been present in the Mediterranean for several decades, was rarely marketed but regularly consumed by fishermen in Lebanon and Syria without any noticeable concern. The sudden appearance of the highly toxic L. sceleratus had a serious impact on those fishermen, who used to eat $L$. spadiceus (Bariche pers. obs.). The large numbers of L. sceleratus that have been caught by coastal fishermen in the eastern Mediterranean has initiated major national efforts to alert fishermen and the public about the toxicity of this fish (Fig. 2).

These efforts have included setting up posters warning the public about the lethal effects if consumed, but also that small individuals could easily be misidentified with other small commercial edible species such as Spicara smaris, Boops boops and Atherina hepsetus (Kalogirou pers. obs.). Studies from the Mediterranean Sea showed that there is a significant positive correlation between toxicity levels and size of fish (Katikou et al., 2009). According to the results of Katikou et al. (2009) individuals smaller than $16 \mathrm{~cm}$ in length do not possess toxicity levels that could be lethal. This reduces the risks in connection with misidentification since commercial S. smaris, B. boops and A. hepsetus rarely exceed this size. 


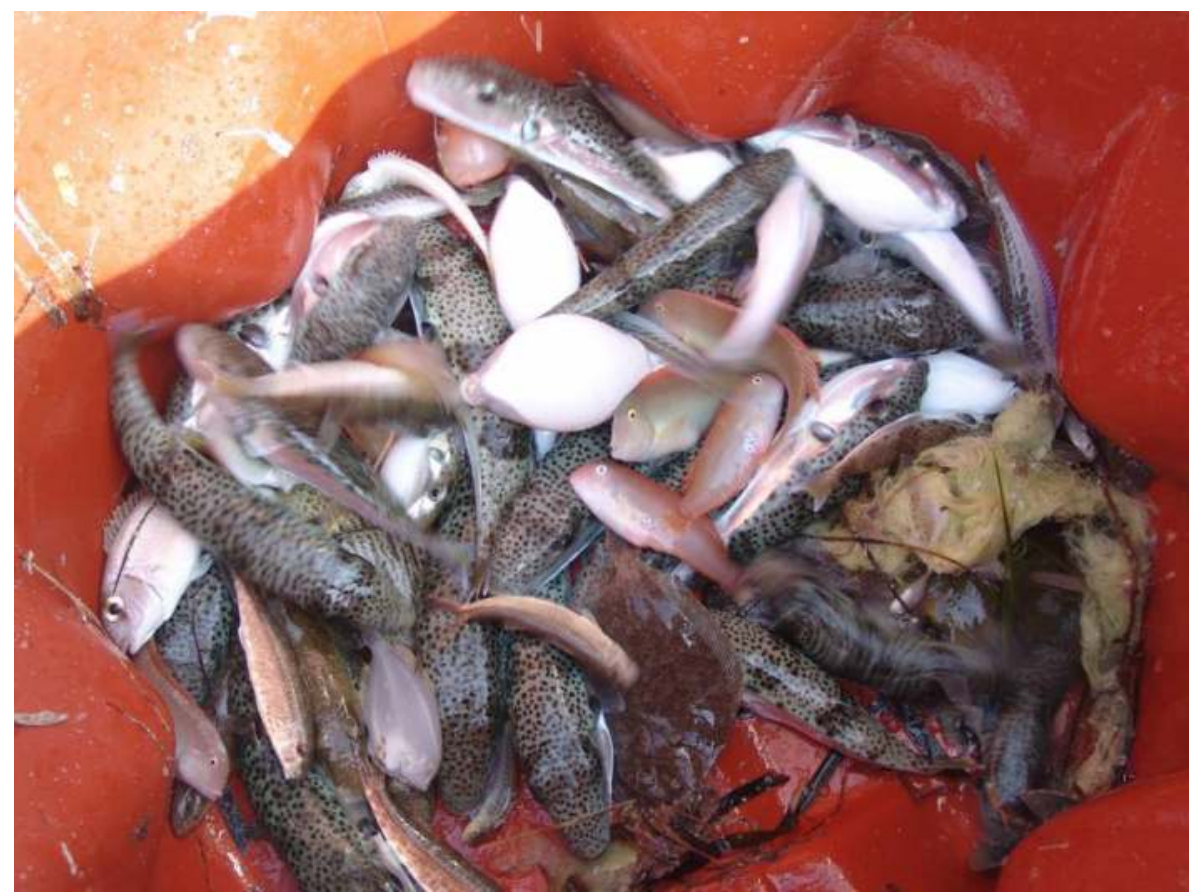

Figure 2. A sampling from sandy bottoms on the coast of Rhodes Island in the southeastern Aegean Sea with a large number of Lagocephalus sceleratus individuals

Lagocephalus sceleratus has also been considered an economical pest by fishermen since it is affected the local fish markets in three ways; deterring customers from buying fish, introducing additional work to discard toxic fish and predating on local stocks of commercially important squids and octopuses (Fig. 3). Lebanese fishermen are considerably affected by the damage caused by L. sceleratus on their fishing gears and catches. In fact, the puffers damage considerably fishing nets and longlines with their strong fused teeth. This is evident from the numerous complaints done by Lebanese fishermen and the presence of fishing hooks and fishing nets fragments respectively in oral cavities and stomachs (Bariche, pers. obs.).

Lagocephalus sceleratus ranked among the 100 'worst' Invasive Alien Species (IAS) in the Mediterranean Sea with profound social and ecological impacts (Streftaris and Zenetos, 2006). Social impacts are obvious due to toxicity but the lack of quantitative data does not support ecological impacts. Despite the successful establishment in the eastern Mediterranean, little is known concerning the ecology of the fish (Kalogirou et al., 2010; Kalogirou et al., 2012b).

An invading species might sometimes go to a peak of density and then decline, a path often called boom and bust (Williamson and Fitter, 1996). This path followed the NIS bluespotted cornetfish Fistularia commersonii in Rhodes Island, SE Aegean Sea (Kalogirou, pers. obs.). When a NIS is established into waters where its preferred food is under-utilized by 


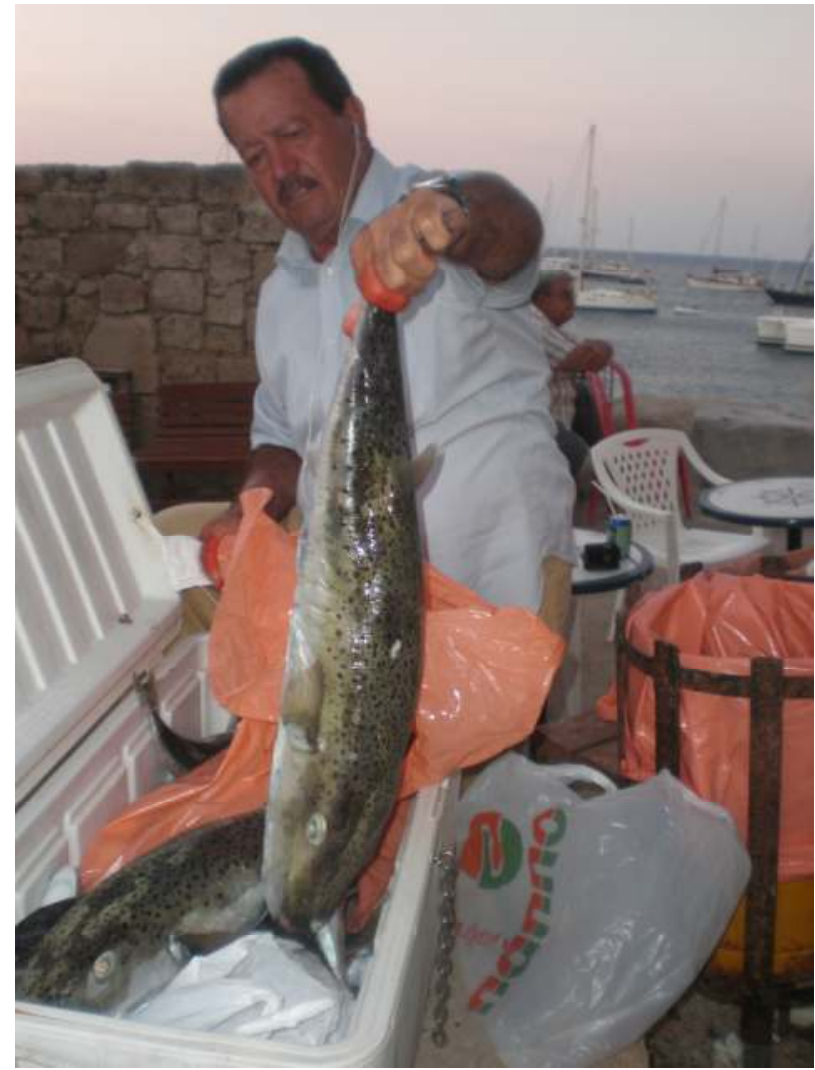

Figure 3. Lagocephalus sceleratus individual from the coast of Rhodes Island in the south-eastern Aegean Sea

indigenous species the resulting population explosion is later brought into equilibrium with available resources. Even though this dynamic leads to the significant reduction of the invading species population size, only very few studies have reported subsequent extinction of the NIS. Competition, despite strong advocacy (Moulton, 1993), seems to be the least likely explanation for most of the examples. Decline and extinction from a build-up of enemies (predators and pathogens) and lack of sufficient resources is more likely to be important explanations in failure of invading animals to establish permanent populations (Williamson and Fitter, 1996).

\section{Do we need new methodologies to monitor current changes of Mediterranean fish diversity?}

Concern has been expressed to the lack of monitoring, coordination, and study in relation to the changing diversity of the Mediterranean Sea. As a matter of fact, exotic fishes spreading in the Mediterranean Sea are usually found by chance as specific procedures for their detection 
are lacking (Azzurro, 2010). Consequently, the extent of these changes may be underestimated as usually happens in several other marine systems (Witenberg and Cock, 2001). Increasing efforts are being devoted to the survey of marine habitats but one of the major obstacles to research remains the lack of data at large geographical scales. This would be important to perceive temporal and spatial trends and to fill important existing information gaps. New methodologies involving local communities have recently proved to be successful in discovering trends of change in Mediterranean fish diversity (Azzurro et al., 2011). As a matter of fact, collaboration with local communities are increasingly used to approach the study of large scale changes in the natural world. As a matter of facts some countries, such as Australia and the USA (California; Hawaii) have already started monitoring projects which involve community-based actions for the detection of marine invasive species. People are basically asked to 'monitor' the marine environment around them, in the course of their daily activities and to provide reports of invasions and various tools and detection kits have been developed all around the world with the aim to widely disseminate information about potential invaders to target communities. In a pilot study called 'alien fish alert' fishermen and divers of the Sicily Strait were asked to provide reports of all "unusual occurrences" (Azzurro, 2010). Given the familiarity of fishermen with local species, no training on fish taxonomy was considered necessary and no black list was proposed, with the following slogan: "there is no need of any expertise in identifying alien species - those familiar with our sea will immediately recognize a 'strange' fish that they have never seen before - it is such records that we are after!". An awareness campaign was realized by means of media promotion, posters and personal interactions. As a matter of fact, this organization was found to provide researchers with an excellent tool for early detection of newly established NIS. These activities are encouraged by the European Strategy of Invasive Alien Species for the up-building of public awareness and collection and distribution of information. In a parallel way, a set of posters with NIS fish photos were distributed among fishermen and at fish auctions along the coast of Lebanon and at port authorities and local fish markets of SE Aegean Sea, Greece. These posters showed only selected fish species displaying characteristic and recognizable family appearances, such as Apogonidae, Chaetodontidae, Scaridae etc. Additionally, posters in Lebanon also provided a phone number with a promise of payment when a new species is collected and delivered. Many fishermen showed a positive response to the advertisement and several first records were collected as such (Bariche, 2010a; 2011a; Bariche and Heemstra, 2012).

The collaboration with local fishery communities has several advantages when the species to monitor are fishes in respect to other groups of organisms. Fishery landings also provide quantitative data, samples and additional information. In addition, the identification of many fishes is relatively easy and this is an obvious advantage for their detection (Fig. 3). Therefore, members of local fishery communities, with broad geographical distributions and familiarity of natural environments could play a dynamic role for the early detection of environmental changes.

Another significant example of innovative ideas to monitor fish diversity changes in the Mediterranean Sea was "Local Ecological Knowledge" (LEK). In recent years, LEK has emerged as an alternative information source on species presence or qualitative and 


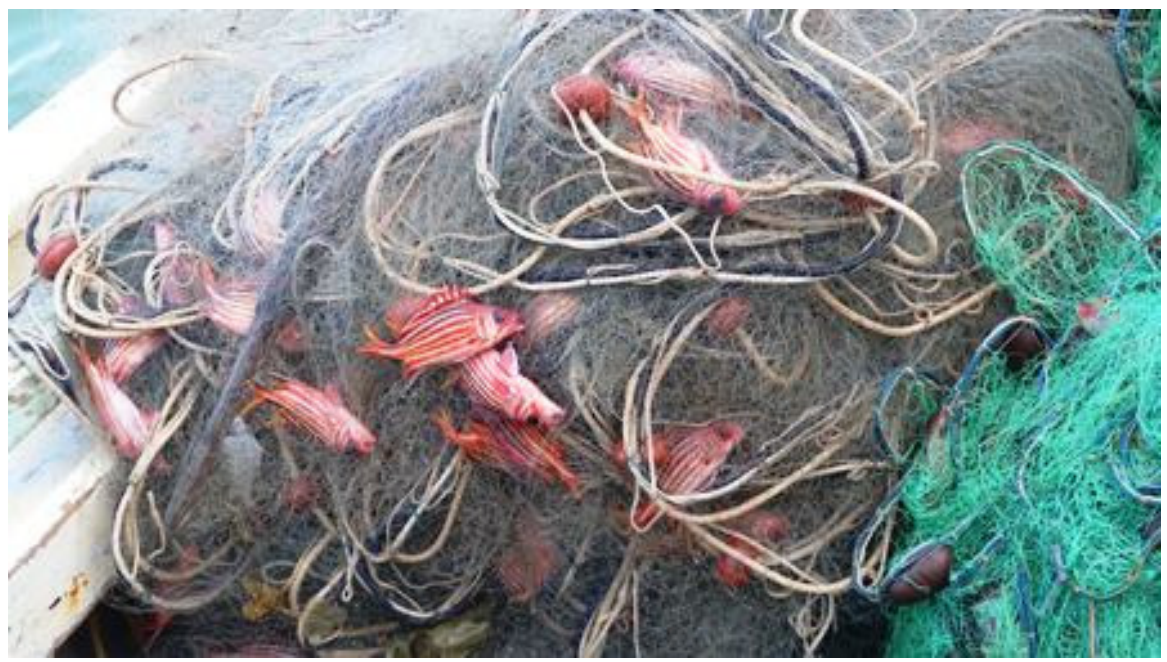

Figure 4. Sargocentrum rubrum individuals caught by trammel nets in Lebanon

quantitative indices of species abundance (Rasalato et al., 2010). Local Ecological Knowledge can be defined as the information that a group of people have about local ecosystems. We usually rely on knowledge gained by individuals over their lifetimes, and not on what information has been handed through generations. To extract data and information from individuals' memory, semi-structured or unstructured conversations between the researcher and the participant were used, a practice commonly called "oral history". In a recent study, Azzurro et al. (2011) provided evidence of a trend for thermophilic taxa to increase in the Central Mediterranean Sea on the basis of a set of interviews to local fishermen. The study was based on interviews to local fishermen and divers with more than ten years of experience. Species mentioned in each interview were used to build a presence-absence dataset that provided extremely coherent results about the northward expansion of families such as Carangidae and Sphyraenidae, whose expansion was only previously noted by occasional records in the scientific literature. These new methodologies give us the chance to get information that otherwise cannot be obtained from the efforts of single researchers. Hopefully in the next future their potential will be increasingly exploited for the monitoring and the understanding of the biodiversity changes in the Mediterranean Sea.

\section{Author details}

Stefanos Kalogirou

Hellenic Centre for Marine Research, Hydrobiological Station of Rhodes, Greece

Ernesto Azzurro

ISPRA, National Institute for Environmental Protection and Research, Livorno, Italy

Michel Bariche

Department of Biology, American University of Beirut, Beirut, Lebanon 


\section{References}

Akyol, O., Unal, V., Ceyhan, T. \& Bilecenoglu, M. (2005). First confirmed record of Lagocephalus sceleratus Gmelin, 1789 in the Mediterranean Sea. Journal of fish biology 66, 1183-1186.

Aydin, M. (2011). Growth, reproduction and diet of pufferfish (Lagocephalus sceleratus Gmelin, 1789) from Turkey's Mediterranean sea coast. Turkish Journal of Fisheries and Aquatic Sciences 11, 589-596.

Azzurro, E., ed. (2008). The advance of thermophilic fishes in the Mediterranean sea: overview and methodological questions. Monaco: CIESM Workshop Monographs

Azzurro, E. (2010). Unusual occurences of fish in the Mediterranean Sea: an insight into early detection. In Fish invasions of the Mediterranean Sea: Change and Renewal (Golani, D. \& Appelbaum-Golani, B., eds.). Sofia-Moscow: Pensoft.

Azzurro, E., Fanelli, E., Mostarda, E., Catra, M. \& Andaloro, F. (2007a). Resource partitioning among early colonizing Siganus luridus and native herbivorous fish in the Mediterranean: an integrated study based on gut-content analysis and stable isotope signatures. Journal of the Marine Biological Association of the UK 87, 991-998

Azzurro, E., Moschella, P. \& Maynou, F. (2011). Tracking Signals of Change in Mediterranean Fish Diversity Based on Local Ecological Knowledge. PLoS ONE 6, e24885.

Azzurro, E., Pais, A., Consoli, P. \& Andaloro, F. (2007b). Evaluating daynight changes in shallow Mediterranean rocky reef fish assemblages by visual census. Marine Biology 151, 2245-2253.

Bariche, M. (2005). Age and growth of Lessepsian rabbitfish from the eastern Mediterranean. Journal of Applied Ichthyology 21, 141-145.

Bariche, M. (2006). Diet of the Lessepsian fishes, Siganus rivulatus and S. luridus (Siganidae) in the eastern Mediterranean: A bibliographic analysis. Cybium 30, 41-49.

Bariche, M. (2010a). Champsodon vorax (Teleostei: Champsodontidae), a new alien fish in the Mediterranean. Aqua, International Journal of Ichthyology 16, 197-200.

Bariche, M. (2010b). Champsodon vorax (Teleostei: Champsodontidae), a new alien fish in the Mediterranean. Aqua 16, 197-200.

Bariche, M. (2011a). First record of the cube boxfish Ostracion cubicus (Ostraciidae) and additional records of Champsodon vorax (Champsodontidae) from the Mediterranean. Aqua, International Journal of Ichthyology 17, 181-184.

Bariche, M. (2011b). First record of the cube boxfish Ostracion cubicus (Ostraciidae) and additional records of Champsodon vorax (Champsodontidae) from the Mediterranean. Aqua, International Journal of Ichthyology 17, 181-184.

Bariche, M., Alwan, N., El-Assi, H. \& Zurayk, R. (2009). Diet composition of the Lessepsian bluespotted cornetfish Fistularia commersonii in the eastern Mediterranean. Journal of Applied Ichthyology 24, 460-465.

Bariche, M., Alwan, N. \& El-Fadel, M. (2006). Structure and biological characteristics of purse seine landings off the Lebanese coast (eastern Mediterranean). Fisheries Research $82,246-252$.

Bariche, M. \& Heemstra, P. (2012). First record of the blackstrip grouper Epinephelus fasciatus (Teleostei: Serranidae) in the Mediterranean Sea. Marine Biodiversity Records 5.

Bariche, M., Letourneur, Y. \& Harmelin-Vivien, M. (2004). Temporal fluctuations and settlement patterns of native and lessepsian herbivorous fishes on the Lebanese coast (Eastern Mediterranean). Environmental Biology of Fishes 70, 81-90. 
Bariche, M. \& Saad, M. (2008). Settlement of the lessepsian blue-barred parrotfish Scarus ghobban (Teleostei: Scaridae) in the eastern Mediterranean. Marine Biodiversity Records 1, e5.

Bariche, M., Sadek, R., Al-Zein, M. S. \& El-Fadel, M. (2007). Diversity of juvenile fish assemblages in the pelagic waters of Lebanon (eastern Mediterranean). Hydrobiologia 580, 109-115.

Ben-Tuvia, A. (1973). Man-made changes in the eastern Mediterranean Sea and their effect on the fishery resources. Marine Biology 19, 197-203.

Ben-Yami, M. \& Glaser, T. (1974). The invasion of Saurida undosquamis (Richardson) into te Levant basin - an example of biological effect on interoceanic canals. Fishery Bulletin 72, 359-373.

Bentur, Y., Ashkar, J., Lurie, Y., Levy, Y., Azzam, Z. S., Litmanovich, M., Golik, M., Gurevych, B., Golani, D. \& Eisenman, A. (2008). Lessepsian migration and tetrodotoxin poisoning due to Lagocephalus sceleratus in the eastern Mediterranean. Toxicon 52, 964-968.

Bianchi, C. (2007). Biodiversity issues for the forthcoming tropical Mediterranean Sea. Hydrobiologia 580, 7-21.

Bianchi, C. N. \& Morri, C. (2003). Global sea warming and "tropicalization" of the Mediterranean Sea: biogeographic and ecological aspects Biogeographia 24, 319-328.

Bianchi, C. N. \& Morri, C. (2004). Climate change and biological response in Mediterranean Sea ecosystems - a need for broad-scale and long-term research. Ocean Challenge 13.

Bilecenoglu, M. (2010). Alien marine fishes of Turkey - an updated review. In Fish Invasions of the Mediterranean Sea: Change and Renewal (Golani, D. \& Appelbaum-Golani, B., eds.), pp. 189-217. Sofia-Moscow: Pensoft Publishers.

Carpentieri, P., Lelli, S., Colloca, F., Mohanna, C., Bartolino, V., Moubayed, S. \& Ardizzone, G. D. (2009). Incidence of lessepsian migrants on landings of the artisanal fishery of south Lebanon. Marine Biodiversity Records 2.

Cicek, E. \& Bilecenoglu, M. (2009). A new alien fish in the Mediterranean Sea: Champsodon nudivittis (Actinopterygii: Perciformes: Champsodontidae). Acta Ichtyological Et Piscatoria 39, 67-69.

CIESM (2008). Climate warming and related changes in the Mediterranean marine biota. In CIESM Workshop Monographs (Briand, F., ed.), p. 152. Monaco.

Diamant, A. (2010). Red-Med immigration: a fish parasitology perspective, with special reference to Mxyxosporea. In Fish Invasions of the Mediterranean Sea: Change and Renewal (Golani, D. \& Appelbaum-Golani, B., eds.), pp. 85-97. Sofia-Moscow: Pensoft Publishers.

EastMed (2010). Report of the sub-regional technical meeting on the lessepsian migration and its impact on eastern Mediterranean fishery. p. 25. GCP/INT/041/EC-GRE-ITA/TD-04.

Galil, B. \& Zenetos, A. (2002). A sea change - Exotics in the eastern Mediterranean. In Invasive Aquatic Species of Europe: Distribution, Impacts and Management (Leppakoski, E., Olenin, S. \& Gollasch, S., eds.), pp. 325-336: Kluwer Academic Publishers.

Galil, B. S. (2006). The marine caravan - the Suez Canal and the Erythrean invasion. In Bridging divides (Gollasch, S., Galil, B. S. \& Cohen, A., eds.), pp. 207-300. Netherlands: Springer.

Galil, B. S. (2007). Loss or gain? Invasive aliens and biodiversity in the Mediterranean Sea. Marine Pollution Bulletin 55, 314-322.

George, C. J. \& Athanassiou, V. A. (1967). A two year study on the fishes appearing in the seine fishery of the St. George bay, Lebanon Ann. Mus. Civ. Stor. Nat. Genova 76, 237-294. 
Golani, D. (1993a). The biology of the Red Sea migrant, Saurida undosquamis in the Mediterranean and comparison with the indigenous confamilial Synodus saurus (Teleostei: Synodontidae). Hydrobiologia 271, 109-117.

Golani, D. (1993b). Trophic adaption of Red Sea fishes to the eastern Mediterranean environment - Review and new data. Israel Journal of Zoology 39, 391-402.

Golani, D. (1994). Niche separation between colonizing and indigenous goatfish (Mullidae) along the Mediterranean coast of Israel. Journal of fish biology 45, 503-513.

Golani, D. (2010). Colonization of the Mediterranean by Red Sea fishes via the Suez Canal Lessepsian migration. In Fish Invasions of the Mediterranean Sea: Change and Renewal (Golani, D. \& Appelbaum-Golani, B., eds.), pp. 145-188. Sofia-Moscow: Pensoft Publishers.

Golani, D. \& Ben-Tuvia, A. (1995). Lessepsian migration and the Mediterranean fisheries of Israel. In World Fisheries Congress (Armentrout, N. B., ed.), pp. 279-289. New Delhi: Oxford \& IBH Publishing Company.

Goldschimdt, T., Witte, F. \& Wanink, J. (1993). Cascading effects of the Introduced Nile Perch on the Detrivorous/ Phytoplanktivorous Species in the Sublittoral Areas of Lake Victoria Conservation Biology 7, 686-700.

Goren, M. \& Galil, B. S. (2001). Fish Biodiversity in the Vermetid Reef Of Shiqmona (Israel). Marine Ecology 22, 369-378.

Goren, M. \& Galil, B. S. (2005). A review of changes in the fish assemblages of Levantine inland and marine ecosystems following the introduction of non-native fishes. Journal of Applied Ichthyology 21, 364-370.

Gottlieb, E. (1960). On the selection of Upeneus moluccensis and Mullus barbatus by trawl codends in the Israeli fisheries. General Fisheries Council for the Mediterranean 8, 1-10 + VI.

Gruvel, A. (1931). Les Etats de Syria. Richness marines et fluviales. Exploitation actuelle, avenir. . In Societe d'editions Geographiques, Marines et Coloniales, pp. 72-134. Paris.

Gucu, A. C. \& Bingel, F. (1994). Trawlable species assemblages on the continental shelf of the Northeastern Levan Sea (Mediterranean) with an emphasis on Lessepsian migration. Acta Adriatica 35, 83-100.

Guidetti, P., Bianchi, C. N., La Mesa, G., Modena, M., Morri, C., Sara, G. \& Vacchi, M. (2002). Abundance and size structure of Thalassoma pavo (Pisces: Labridae) in the western Mediterranean Sea: variability at different spatial scales. Journal of the Marine Biological Association of the United Kingdom 82, 495-500.

Harmelin-Vivien, M. L., Bitar, G., Harmelin, J.-G. \& Monestiez, P. (2005). The littoral fish community of the Lebanese rocky coast (eastern Mediterranean Sea) with emphasis on Red Sea immigrants. Biological Invasions 7, 625-637.

Hassan, M., Harmelin-Vivien, M. \& Bonhomme, F. (2003). Lessepsian invasion without bottleneck: example of two rabbitfish species (Siganus rivulatus and Siganus luridus). Journal of Experimental Marine Biology and Ecology 291, 219-232.

Jackson, J. B. C., Kirby, M. X., Berger, W. H., Bjorndal, K. A., Botsford, L. W., Bourque, B. J., Bradbury, R. H., Cooke, R., Erlandson, J., Estes, J. A., Hughes, T. P., Kidwell, S., Lange, C. B., Lenihan, H. S., Pandolfi, J. M., Peterson, C. H., Steneck, R. S., Tegner, M. J. \& Warner, R. R. (2001). Historical Overfishing and the Recent Collapse of Coastal Ecosystems. Science 293, 629-637.

Kalogirou, S., Corsini Foka, M., Sioulas, A., Wennhage, H. \& Pihl, L. (2010). Diversity, structure and function of fish assemblages associated with Posidonia oceanica beds in an 
area of the eastern Mediterranean Sea and the role of non-indigenous species. Journal of fish biology 77, 2338-2357.

Kalogirou, S., Corsini, M., Kondilatos, G. \& Wennhage, H. (2007). Diet of the invasive piscivorous fish Fistularia commersonii in a recently colonized area of eastern Mediterranean. Biological Invasions 9, 887-896.

Kalogirou, S., Mittermayer, F., Pihl, L. \& Wennhage, H. (2012a). Feeding ecology of indigenous and non-indigenous fish species within the family Sphyraenidae. Journal of fish biology 80, 2528-2548.

Kalogirou, S., Wennhage, H. \& Pihl, L. (2012b). Non-indigenous species in Mediterranean fish assemblages: Contrasting feeding guilds of Posidonia oceanica meadows and sandy habitats. Estuarine, Coastal and Shelf Science 96, 209-218.

Kan, S., Chan, M. K. \& David, P. (1987). Nine fatal cases of Puffer fish poisoning in Sabah, Malaysia. Medical Journal of Malaysia 42, 199-200.

Katikou, P., Georgantelis, D., Sinouris, N., Petsi, A. \& Fotaras, T. (2009). First report on toxicity assessment of the Lessepsian migrant pufferfish Lagocephalus sceleratus (Gmelin, 1789) from European waters (Aegean Sea, Greece). Toxicon 54, 50-55.

Lasram, F. B. R., Guilhaumon, F. \& Mouillot, D. (2009). Fish diversity patterns in the Mediterranean Sea: deviations from a mid-domain model. Marine Ecology Progress Series 376, 253-267.

Lasram, F. B. R. \& Mouillot, D. (2008). Increasing southern invasion enhances congruence between endemic and exotic Mediterranean fish fauna. Biological Invasions.

Leppäkoski, E. \& Olenin, S. (2000). Non-native species and rates of spread: lessons from the brackish Baltic Sea. Biological Invasions 2, 151-163.

Levine, J. M. \& Adler, P. B. (2004). A meta-analysis of biotic resistance to exotic plant invasions. Ecology Letters 7, 975-989.

Levine, J. M. \& D' Antonio, C. M. (1999). Elton revisited: a review of evidence linking diversity and invasibility. Oikos $87,15-26$.

Lipkin, J. \& Safriel, U. N. (1971). Intertidal zonation on rocky shores at Mikhmoret (Mediterranean, Israel). J. Ecol. 59, 1-30.

Lundberg, B. \& Golani, D. (1995). Diet adaptations of Lessepsian migrant rabbitfishes, Siganus luridus and S. rivulatus, to the algal resources of the Mediterranean coast of Israel. Marine Ecology 16, 73-89.

Lundberg, B., Ogorek, R., Galil, B. S. \& Goren, M. (2004). Dietary choices of siganid fish in Shiqmona reef, Israel. Israel Journal of Zoology 50, 39-53.

MacArthur, R. (1955). Fluctuations of Animal Populations and a Measure of Community Stability. Ecology 36, 533-536.

Massuti, E., Valls, M. \& Ordines, F. (2010). Changes in the western Mediterranean ichthyofauna: signs of tropicalization and meridianization. In Fish Invasions of the Mediterranean Sea: Change and Renewal (Golani, D. \& Appelbaum-Golani, B., eds.), pp. 293-312. Sofia-Moscow: Pensoft Publishers.

Moulton, M. P. (1993). The all-or-none pattern in introduced Hawaiian passeriforms: The role of competition sustained. The American Naturalist 141, 105-119.

Moyle, P. B. \& Light, T. (1996). Biological invasions of fresh water: Empirical rules and assembly theory. Biological Conservation 78, 149-161. 
Occhipinti-Ambrogi, A. \& Savini, D. (2003). Biological invasions as a component of global change in stressed marine ecosystems. Marine Pollution Bulletin 46, 542-551.

Oren, O. H., Ben-Yami, M. \& Zismann, L. (1971). Explorations of the possible deep-water trawling grounds in the Levant basin. Proceedings of the General Fisheries Council for the Mediterranean, Studies and Reviews 49, 41-71.

Parmesan, C. \& Yohe, G. (2003). A globally coherent fingerprint of climate change impacts across natural systems. Nature 421, 37-42.

Perry, A. L., Low, P. J., Ellis, J. R. \& Reynolds, J. D. (2005). Climate Change and Distribution Shifts in Marine Fishes. Science 308, 1912-1915.

Por, F. D. (1978). Lessepsian migration: the influx of Red Sea biota into the Mediterranean by way of the Suez canal. Berlin-Heidenberg: Springer.

Quignard, J. P. \& Tomasini, J. A. (2000). Mediterranean fish biodiversity. Biologia Marina Mediterranea 7, 1-66.

Raitsos, D. E., Beaugrand, G., Georgopoulos, D., Zenetos, A., Pancucci-Papadopoulou, A. M., Theocharis, A. \& Papathanassiou, E. (2010). Global climate change amplifies the entry of tropical species into the eastern Mediterranean Sea. Limnology and Oceanograph 55, 1478-1484.

Rasalato, E., Maginnity, V. \& Brunnschweiler, J. M. (2010). Using local ecological knowledge to identify shark river habitats in Fiji (South Pacific). Environmental Conservation 37, 90-97.

Reise, K., Olenin, S. \& Thieltges, D. (2006). Are aliens threatening European aquatic coastal ecosystems? Helgoland Marine Research 60, 77-83.

Ricciardi, A. (2001). Facilitative interactions among aquatic invaders: is an "invasional meltdown" occurring in the Great Lakes? Canadian Journal of Fisheries and Aquatic Sciences 58, 2513-2525.

Ricciardi, A. \& Mottiar, M. (2006). Does Darwin's naturalization hypothesis explain fish invasions? Biological Invasions 8, 1403-1407.

Rilov, G. \& Crooks, J. A. (2009). Marine Bioinvasions: Conservation Hazards and Vehicles for Ecological Understanding. In Biological Invasions in Marine Ecosystems (Rilov, G. \& Crooks, J. A., eds.). Berlin Heidenberg: Springer-Verlag.

Rilov, G. \& Galil, B. (2009). Marine bioinvasions in the Mediterranean Sea - History, distribution and ecology. In Biological Invasions in Marine Ecosystems (Rilov, G. \& Crooks, J. A., eds.), pp. 549-575. Berlin Heidelberg: Springer.

Roessig, J. M., Woodley, C. M., Cech, J. J. \& Hansen, L. J. (2004). Effects of global climate change on marine and estuarine fishes and fisheries. Reviews in Fish Biology and Fisheries 14, 251-275.

Sabrah, M. M., El-Ganainy, A. A. \& Zaky, M. A. (2006). Biology and toxicity of the pufferfish Lagocephalus sceleratus (Gmelin, 1789) from the gulf of Suez Egyptian Journal of Aquatic Research 32, 283-297.

Sakinan, S. \& Örek, Y. A. (2011). First record of Indo-Pacific Indian scad fish, Decapterus russelli, on the north-eastern Mediterranean coast of Turkey. Marine Biodiversity Records 4.

Salameh, P., Sonin, O., Edelis, D. \& Golani, D. (2011). First record of the Red Sea orangeface butterflyfish Chaetodon larvatus Cuvier, 1831 in the Mediterranean. Aquatic Invasions 6, S53-S55.

Sax, D. F. (2002). Native and naturalized plant diversity are positively correlated in scrub communities of California and Chile. Diversity and Distributions 8, 193-210. 
Sax, DovB F., Gaines, StevenB D. \& Brown, JamesB H. (2002). Species Invasions Exceed Extinctions on Islands Worldwide: A Comparative Study of Plants and Birds. The American Naturalist 160, 766-783.

Shakman, E. A. \& Kinzelbach, R. (2007). Distribution and characterization of lessepsian migrant fishes along the coast of Libya. Acta Ichtyological Et Piscatoria 37, 7-15.

Simberloff, D. \& Von Holle, B. (1999). Positive Interactions of Nonindigenous Species: Invasional Meltdown? Biological Invasions 1, 21-32.

Sonin, O., Spanier, E. \& Pisanty, S. (1996). Undersized fishes in the catch of the Israeli Mediterranean fisheries - are there differences between shallow and deeper water ? In Preservation of our world in the wake of change (Steinberger, ed.), pp. 449-454. Jerusalem: ISEEQS Publication.

Stachowicz, J. J. \& Tilman, D. (2005). Species invasions and the relationships between species diversity, community saturation, and ecosystem functioning. In Species Invasions: Insights into ecology, evolution and biogeography (Sax, D. F., Stachowicz, J. J. \& Gaines, S. D., eds.). Sunderland, Massachusetts: Sinauer Associates.

Stachowicz, J. J. \& Whitlatch, R. B. (1999). Species Diversity and Invasion Resistance in a Marine Ecosystem. Science 286, 1577.

Streftaris, N. \& Zenetos, A. (2006). Alien marine species in the Mediterranean - the 100 'worst invasives' and their impact. Mediterranean Marine Science 7, 87-118.

Streftaris, N., Zenetos, A. \& Papathanassiou, E. (2005). Globalisation in marine ecosystems The story of non indigenous marine species across European Seas. Reviews in Oceanography and Marine Biology 43, 419-454.

Vitousek, P. M., Mooney, H. A., Lubchenco, J. \& Melillo, J. M. (1997). Human Domination of Earth's Ecosystems. Science 277, 494-499.

Wallentinus, I. \& Nyberg, C. D. (2007). Introduced marine organisms as habitat modifiers. Marine Pollution Bulletin 55, 323-332.

Williamson, M. H. \& Fitter, A. (1996). The characters of successful invaders. Biological Conservation 78, 163-170.

Witenberg, R. \& Cock, M. J. W., eds. (2001). Invasive alien species: a toolkit of best prevention and management practices: GISP.

Yang, C. C., Liao, S. C. \& Deng, J. F. (1996). Tetrodotoxin poisoning in Taiwan; an analysis of posion center data. Veterinary and Human Toxicology 38, 282-286.

Zenetos, A., Gofas, S., Verlaque, M., Cinar, M. E., Garcia Raso, J. E., Bianchi, C. N., Morri, C., Azzurro, E., Bilecenoglu, M., Froglia, C., Siokou I., Violanti, D., Sfriso, A., San Mart, G., Giangrande, A., Kata An, T., Ballesteros, E., Ramos-Espla, A., Mastrototaro, F., Oca A, O., Zingone, A., Gambi, M. C. \& Streftaris, N. (2010). Alien species in the Mediterranean Sea by 2010. A contribution to the application of European Union's Marine Strategy Framework Directive (MSFD). Part I. Spatial distribution. Mediterranean Marine Science 11, 381-493.

Zenetos, A., Meric, E., Verlaque, M., Galli, P., Boudouresque, C.-F., Giangrande, A., Cinar, E. \& Bilecenoglu, M. (2008). Additions to the annotated list of marine alien biota in the Mediterranean with special emphasis on Foraminifera and Parasites. Mediterranean Marine Science 9, 119-165.

Zenetos, A., Pancucci Papadopoulou, M. A., Zogaris, S., Papastergiadou, A., Vardakas, L., Aligizaki, K. \& Economou, A. N. (2009). Aquatic alien species in Greece: tracking sources, patterns and effects on the ecosystem. Journal of Biological Research-Thessaloniki 12, 135-172. 